of measuring the thickness of metal walls from one surface only by electrical means. A reference was made to this device by Prof. Thornton in his contribution to the discussion on non-destructive testing at the Institution of Electrical Engineers on November 25. He states that there is a definite need in the engineering industry for an instrument which will determine accurately the thickness of a metal wall from one side only, especially if it is easy to operate, robust, portable, and independent of external power supply. It is claimed that the instrument described in the paper fulfils all these conditions. The method is essentially that of comparing the resistance of the metal wall under test with that of a similarly shaped wall of the same material, of which the thickness is known. Current, usually less than ten amperes, is supplied by a 12-volt battery to two current contacts held against the wall and usually spaced about three inches apart. The current in the circuit is adjusted by varying the rheostat or the number of cells of the small motor-car battery employed, until the very small potential drop indicated by the deflection of a galvanometer connected to two potential contacts reaches a predetermined fixed value. The instrument was originally designed for measuring the thickness of boiler-tubes, and examples are given showing that its accuracy is within a few thousandths of an inch. It has been found in practice that the instrument can be used to measure the thickness of mild steel plates up to $1 \cdot 25$ in. and of iron castings up to three inches, with the same order of accuracy. It can also be used for the measurement of engine cylinder walls to detect core shift.

\section{World-Wide Survey of Education}

IN this year's issue of the well-known biennial official survey of education in the United States is included a sketch of the salient features of the history of education in other parts of the world in the decennium 1926-36 (Washington, D.C. : Govt. Printing Office, 1938. Pp. 98. 15 cents). It was an era of drastic-in some countries of revolutionarychanges. In Europe, sudden changes in the direction of educational policies were effected in connexion with general revolutionary movements in Austria, Bulgaria, Germany, Portugal, Spain and the Soviet Union. Pronounced but gradual changes, longplanned and deliberately considered, were introduced in Czechoslovakia, England, France, Norway, Poland and Sweden. The most conspicuous movements in Europe were in the direction of nationalization. One aspect of this tendency was the ousting of private by public schools, notably exemplified in Norway and Albania; another, manifested throughout Europe, was the increasing subjection of private schools to public regulation; another, the placing of more of the support and administration of schools in the hands of national instead of local officials; yet another, the progress attempted, with varying success, towards the goal of equal educational opportunity for equal intelligence. The doctrine that education is a public function has, in fact, achieved general acceptance, and States "have been rapidly taking wider and closer control of their cultural institutions, but not always in the way that advocates of public education have desired".

Nationalization in the extreme sense of subordination of all other educational aims to the purpose of promoting and perpetuating the national Government's political and economic theories and practices was established in Italy, the Soviet Union and Germany. The survey briefly indicates its outstanding features and some sources of information about it. Attention is directed to the fact that in the Soviet Union communistic doctrine has had a much less important place in the school curriculum since 1934 than before. Other sections deal with European educational history under such headings as adult education, physical education, technical and vocational education. A chapter on Latin-America points out that the spirit of intense nationalism so rampant in post-War Europe has manifested itself there also. A formulation of the purposes of the education policy of Colombia, for example, contains the following: "We no longer speak of public instruction but of national education... the state ought to educate, that is to say, form the will and heart of the youth rather than instruct by loading them down with knowledge more or less useful". However, the extreme type of nationalization found in Italy, Germany and the Soviet Union has no counterpart in America except in Mexico, and this example is not likely to be followed, we are told, in other Latin American countries. Throughout these countries a very lively interest in the problems of vocational training has been aroused and developments have taken place that deserve study elsewhere.

\section{Education in Civilian Camps}

A BuLcerin by H. W. Oxley, director of civilian conservation corps camp education, issued by the U.S. Department of the Interior (No. 19, 1937), describes the growth and development of camp education, particularly its achievements in vocational guidance and in recreation. The programme endeavours to develop powers of self-expression, selfentertainment and culture, and to promote co-operation; in addition to vocational instruction, attempts have been made to remove illiteracy and to correct common school deficiencies. The Bulletin also includes a summary of three university studies in counselling and guidance technique in camp education, which indicate that only a beginning has been made in the camps with job and vocational instruction. Most of those enrolled come from the working class, and about 12 per cent of those interviewed had received no vocational guidance. Many of those enrolled regarded the camp as a transition from home to employment, and the studies indicated the necessity for much more comprehensive vocational training and more careful interviewing. A further study of successful practices in the development of a coordinated recreational programme in these camps, in which four universities participated, is also sum. marized in the Bulletin. This analysis of activities 
indicated the pressing need for adequate space, equipment and instructors, and led to a number of definite recommendations for the development of a co-ordinated programme for leisure time in C.C.C. camps.

\section{The Radio and Culture}

AT the recent annual meeting of the Institut de France, Dr. Georges Duhamel, the well-known writer and editor of the Mercure de France, deplored what he called the constitutional defects of the radio, which he declared has an unfavourable and even demoralizing effect on the intellectual habits of the middle classes. In the first place he asserted that the radio draws many persons away from reading by depriving them of part of their leisure and making them gradually lose the habit of active cerebral work. Some people, he continued, are misled by the radio into imagining that the mind can attend to two objects at the same time, which is a mistake. Far from contributing to true culture, the radio encourages a taste for superficial ideas which are easily acquired and soon lost. In answer to the objection that the radio adds to without supplanting the other modes of information and knowledge, Dr. Duhamel maintained that we cannot safely disregard or decry a system of culture which has been tested for centuries in favour of a new process of which the remote results are necessarily quite unknown. As regards the plea that the radio is a source of pleasure, Dr. Duhamel retorted that no pleasure can last several hours a day, and that for some people the radio ceases almost at once to be a pleasure and becomes a craving.

\section{London School of Hygiene and Tropical Medicine}

THE report for 1937-38 of the London School of Hygiene and Tropical Medicine by the dean, Prof. W. Jameson, recently issued, surveys the administrative changes and the teaching and research work of the School during the year. In the Departments of Bacteriology and Epidemiology studies have been in progress for eighteen months on the effect of diet on the fertility, survival and growth of mice, and their resistance to infection, which show that a diet containing a proportion of animal protein, compared with one containing vegetable protein only, renders individual mice more resistant to infection of Bact. typhimurium, and significantly reduces the mortality in herds in which the disease is spreading by natural contact. In the Department of Entomology much work has been done on the biology of mosquitoes, the bed bug, lice and other parasites, and an important investigation continued on the spread of mineral oils on water in relation to anti-malarial work by destruction of mosquito larvæ. In the Department of Bacteriology studies have been continued upon the isolation of the antigenic components from various bacteria, and their value as immunizing agents. The physiological problems of air raids precautions, in particular gasproof clothing, helminthic parasites of domestic animals, and problems connected with the root eelworm disease of potatoes, are a few of the other subjects that are under investigation. The Ross
Institute of Tropical Hygiene reports upon its antimalarial work in various Colonies, Yugoslavia and South America.

\section{Malaria in Albania}

IN an inaugural thesis (Thèse de Paris, No. 548; 1938), F. L. Richards states that malaria is the most prevalent disease in Albania, especially in the low-lying regions. where it is closely associated with the presence of lakes, marshes and other places inundated by the mountain water courses. It is more or less endemic in villages near streams and their affluents. Most of the patients under treatment in the hospitals are suffering from this complaint, which in some parts of the country affects 50 per cent of the population. All clinical forms of the disease are found, malignant tertian being the commonest. In addition to its high incidence in the civilian population, malaria is the most frequent disease in the Albanian army. Its prevalence is highest in June, July, August and September, and sometimes there is a rapid rise in the number of cases in October; but August and September are the months in which the disease is most intense. The death-rate is higher in children than in adults. The spread of the disease is favoured by the unhygienic habits of the Albanian people and is therefore most pronounced among the poor. At the suggestion of the King of Albania, a five-year plan has recently been introduced for combating the disease.

\section{Microscopy for the Chemist}

A Recent article by Prof. Alois Herzog (Zeiss Nach., 2, Hefte 5 and 6, 1938) is based upon the value of the microscope to the chemist for qualitative analytical determinations with minimal amounts of material. A number of simple methods is described involving the use of sublimation, distillation, precipitation, drying, crystallization, spot reactions, and other procedures with or without the addition of specified reagents, whereby crystals and other deposits having characteristic microscopical appearances are obtained, which serve to identify various metals and metallic and other salts, etc. Screens (sieves), animal and vegetable fibres, and miscellaneous inorganic substances like asbestos, and the use of the polarizing microscope are also briefly described. The article is illustrated with 97 excellent photomicrographs of the appearances obtained in the reactions, and full details are given as to how the objects were photographed, namely the camera, objective and ocular used, the illumination and the time of exposure.

\section{Physics in Crime Detection}

The Physics Forum of the November issue of the Review of Scientific Instruments is devoted to an account of the use made of physics in the detection of crime in the United States. It is written by J. Edgar Hoover, of the Federal Bureau of Investigation of the Department of Justice. Although the author refers to the use of radio in rapidly communicating information, the account is mainly con- 